\title{
Exploring The Relationship between Project-Based Learning and Collaborative Skills: EFL Learners' Voices
}

\author{
Santi Andriyani (Corresponding Author) \\ santi@unisnu.ac.id \\ Universitas Islam Nahdlatul Ulama Jepara, Indonesia \\ Syafiul Anam \\ syafiulanam@unesa.ac.id \\ Universitas Negeri Surabaya, Indonesia
}

\begin{abstract}
This research aims to measure EFL learners' perceived projectbased learning and examine whether there is a correlation between projectbased learning and EFL learners' collaborative skills. This research used a correlational study using Spearman Product Moment based on non-parametric data. The data were gathered using a closed-ended questionnaire. The sample consisted of 100 (17 male and 83 female) Indonesian University EFL learners recruited using convenience sampling. The findings indicated that more than $70 \%$ of learners' perceptions of project-based learning positively impact their collaborative skills. The benefits of project-based learning include enhancing learners' motivation, teamwork, communication, creativity, and problemsolving abilities. The next finding is a strong correlation between projectbased learning, which significantly generated Sig. (p-value) $=0.000<\alpha=$ 0.05 . Some previous studies reported that project-based learning positively correlates with collaborative skills.
\end{abstract}

Keywords: EFL learners; project-based learning; collaborative skills.

\section{A. INTRODUCTION}

Creativity and innovation are essential keywords to ensure Indonesia's sustainable development. Students currently studying in tertiary institutions or advanced must be prepared to become natural learners who are skilled, flexible, and tenacious (agile learners). The freedom in learning launched by the Minister of Education and Culture is a framework to prepare students to become strong scholars, relevant to the needs of the times, and ready to become leaders with a high national spirit. Freedom in learning provides challenges and opportunities for the development of creativity (Daly, Mosyjowski, Oprea, Huang-Saad, \& Seifert, 2016) (Jahnke, Haertel, \& Wildt, 2017), 
capacity, personality, and student needs, as well as developing independence in seeking and finding knowledge through reality (The Guideline Book of MBKM :2020).

One of the aspects that can accelerate the freedom in learning is critical performance indicators of the University. Based on the Decree of the Minister of Education and Culture Number $754 / \mathrm{P} / 2020$, it is a new performance measurement for universities to realize adaptive higher education with a more concrete outcome (RI, 2020). One of the indicators is facilitating the collaborative and participative classes to improve students' creativity and innovation.

However, these skills-related goals are not easy to achieve as traditional learning plays a dominant role where teachers are "the transmitter of the knowledge." At the same time, students act as "the receptor of the information. As a result, it is difficult for students to fully engage in educational practices, which may lead to a superficial understanding of disciplinary knowledge. The next problem is the difficulties generating ideas (Heong et al., 2012) and solving the problems (Reddy \& Panacharoensawad, 2017).

In addition, in reality, many problems still occur to students, including learning independence, which will make it challenging to manage time in learning and cannot set targets in completing assignments. The lack of students in independent learning can be proven by students who are not motivated to learn independently, are not tenacious in learning, are not severe, are not disciplined, and are not responsible for what they do. The research results showed that $64.06 \%$ of students had difficulty solving problems; $53.13 \%$ had trouble finding alternative solutions to the issues given (Sugiyanto \& Suryandari: 2020).

Collaboration is one of the challenges of 21st-century skills (Esfratia, 2014). Collaborative skill is now considered essential in almost all areas of life. Collaborating enhances the students' motivation and promotes active learning (Mora, Signes-Pont, Fuster-Guilló, \& Pertegal-Felices, 2020). In addition, this method can be beneficial and time-saving for instructors in managing large groups. Collaborative learning is an educational approach to teaching and learning involving groups of learners working together to solve a problem, complete a task, or create a product. In the Collaborative learning environment, the learners are challenged both socially and emotionally as they listen to different perspectives and are required to articulate and defend their ideas (Laal \& Ghodsi, 2012). Project-based learning can promote students' collaboration. There is an 
influence of project-based learning models on student collaboration skills (Rasyid \& Khoirunnisa, 2021).

In order to change this situation, it is suggested that students are provided with the opportunity to participate in real problem-solving and knowledge construction in authentic professional contexts. One attractive way to achieve this goal is project-based learning (PBL). PBL is a comprehensive instructional approach that engages students in an organized and cooperative manner to investigate and resolve a particular problem (Musa, Mufti, Latiff, \& Amin, 2011). Students drive their learning through inquiry and work collaboratively to research and create projects that reflect their knowledge (Setia Dewi, 2020). Thus, students need to learn higher-order thinking skills to address the difficulty in generating ideas. Some findings prove the advantages of project-based learning. Using PBL gives some positive feelings of lecturers (development of students' competencies, a collaboration between a lecturer and a student, lecturer's professional development) create conditions for their professional self-realization and continuous improvement (Rao, 2019).

PBL model also supports the teaching and English learning processes. Through this method, students engage in purposeful communication to complete authentic activities tasks that are relevant to and useful in the real world. As a result, they have the opportunity to use language in a relatively natural context and participate in meaningful activities that require authentic language use (Lam, 2011). The students' reasoning and creativity are improved (Ngadiso, Sarosa, Asrori, Drajati, \& Handayani, 2021). In addition, using project-based learning in English as a foreign language instruction increases EFL learners' motivation, interest, and performance (Tsiplakides \& Fragoulis, 2009). Some findings prove the positive effects of project-based learning on collaborative skills for EFL learners. Project-based learning can promote students' collaboration (Rasyid \& Khoirunnisa, 2021), engage motivations to learn English (Wongdaeng \& Hajihama, 2018), allow sharing of students' ideas (Rao, 2019).

This study aims to analyze the learners' perception of project-based learning; 2) examine the relationship between project-based learning and collaborative skills of EFL learners. Therefore, the research questions are (a) how do learners' perceive project-based learning?; b) is there any correlation between students' perception of project-based learning to collaborative skills? 


\section{B. RESEARCH METHOD}

\section{Design}

This correlational research design measures the relationship between project-based learning and collaborative skill. This study used a statistical approach to analyze the reliability and validity of the instrument and to answer the research questions.

\section{Participants}

This study recruited 100 Indonesian EFL learners, comprising both males $(\mathrm{n}=17)$ and females $(n=83)$. The participant age from 17-20 $(n=56)$ whereas the participant age from 21-25 ( $\mathrm{n}=86$ ). Convenience sampling was employed to recruit all participants. It means the participants were selected based on their availability.

\section{Setting and Research Instrument}

This research was taken place at the Islamic University of Nahdlatul Ulama Jepara. It will be obtained from students of English Language Education Departments involved in project-based English learning. The researcher used a questionnaire to determine the students' perception of project-based learning to collaborative skills. The questionnaire is prepared using five-point Likert scales (from strongly disagree to agree strongly).

The dependent variable is students' collaborative skills, measured by the questioners adopted from Musa. et al. (2016). The questioners are adopted from (Alyani, 2021). The independent variables are the components of project-based learning. They are; 1) questioning, designing, scheduling, monitoring, assessing, and evaluating.

The next step was to assess the reliability and validity of the questionnaire. The Cronbach's alpha was .879 , suggesting high internal consistency in terms of overall reliability. Therefore, the questionnaire was suitable for measuring the concept of PBL and Collaborative skills. Several experts in the field were consulted to evaluate its accuracy to ensure content validity. All the items included in this instrument were collectively negotiated and agreed upon by all the invited experts.

\section{Data Analysis Technique}

Due to the limited number of research participants, therefore normality and heterogeneity of the sample were not statistically met. Henceforth, non-parametric statistical analysis was employed to analyze the data. The quantitative data were analyzed using Descriptive statistics. Spearman Rank Test was used to investigate whether there is a relationship between PBL and Collaborative skill. 


\section{FINDINGS AND DISCUSSION}

\section{Findings}

The characteristics of the EFL learners as respondents are summarized in table 1 below. The e-questionnaire using Google from was filled up by 100 students ,comprised of $17 \%$ male students $(n=17)$ and $83 \%$ female students $(n=83)$. The students' age between $17-20$ are $56 \%(n=56)$ and $21-25$ are $44 \%(n=44)$

\section{Table 1 : Information of participants}

\begin{tabular}{cc} 
Participants Characteristicts & $N(\boldsymbol{\%})$ \\
\hline Male & $17(17 \%)$ \\
\hline Female & $83(83 \%)$ \\
\hline Students' aged between 17-20 & $56(56 \%)$ \\
\hline Students' aged between $21-25$ & $44(44 \%)$
\end{tabular}

\section{EFL Learners' Perceive Project-Based Learning}

EFL Learners' perception of project-based learning is measured by 17 items using a 5-point Likert scale. Item 1 and 3 focused on questioning component of PBL, items 3 , 4,5,6,7 concentrated on designing a component of PBL, item 8,9,10 focused on scheduling component of PBL, items 11,12,13 focused on monitoring component of PBL, item 14, 15 focused on assessing component of PBL, and item 16, 17 focused on evaluating part of PBL.

Table 2: The EFL Learners Perceive Project-Based Learning

\begin{tabular}{|c|c|c|c|c|c|c|}
\hline Item & Statement & $\begin{array}{c}\text { Strongly } \\
\text { Agree }\end{array}$ & Agree & Uncertain & Disagree & $\begin{array}{l}\text { Strongly } \\
\text { Disagree }\end{array}$ \\
\hline \multicolumn{7}{|c|}{ Questioning } \\
\hline 1 & $\begin{array}{l}\text { I found that } \\
\text { brainstorming helps } \\
\text { to activate students' } \\
\text { past knowledge and } \\
\text { interest and motivate } \\
\text { them to learn more } \\
\text { about the subject }\end{array}$ & $18(18 \%)$ & $\begin{array}{c}79 \\
(79 \%)\end{array}$ & $3(3 \%)$ & $0(0 \%)$ & $0(0 \%)$ \\
\hline 2 & $\begin{array}{l}\text { The driving question } \\
\text { keeps the students } \\
\text { focus on the project } \\
\text { which is relevant } \\
\text { with their real life } \\
\text { situation and makes } \\
\text { them more active } \\
\text { and successfully } \\
\text { solve the problem }\end{array}$ & $\begin{array}{c}17 \\
(17 \%)\end{array}$ & $\begin{array}{c}77 \\
(77 \%)\end{array}$ & $5(5 \%)$ & $1(1 \%)$ & $0(0 \%)$ \\
\hline
\end{tabular}


Item 1 showed that the EFL learners choose strongly agree $18 \%(n=18)$, followed by agree statement 79\% (n=79), uncertain 3\% (n=3), and no one considered disagree and strongly disagree. Item 2 showed that the EFL learners choose strongly agree 17\% ( $n=17)$, followed by agree statement $77 \%(n=77)$, uncertain $5 \%(n=5)$, disagree $1 \%(n=1)$, and no one considered strongly disagree.

\begin{tabular}{|c|c|c|c|c|c|c|}
\hline Item & Statement & $\begin{array}{c}\text { Strongly } \\
\text { Agree }\end{array}$ & Agree & Uncertain & Disagree & $\begin{array}{l}\text { Strongly } \\
\text { Disagree }\end{array}$ \\
\hline \multicolumn{7}{|c|}{ Designing } \\
\hline 3 & $\begin{array}{l}\text { Discussing the steps } \\
\text { of activities along } \\
\text { with students help } \\
\text { them taking } \\
\text { ownership of the } \\
\text { project }\end{array}$ & $\begin{array}{l}19 \\
(19 \%)\end{array}$ & $\begin{array}{l}75 \\
(75 \%)\end{array}$ & $6(6 \%)$ & $0(0 \%)$ & $0(0 \%)$ \\
\hline 4 & $\begin{array}{l}\text { As students are } \\
\text { divided into several } \\
\text { groups for the } \\
\text { project, it improves } \\
\text { their collaboration } \\
\text { skills as they engage } \\
\text { and share } \\
\text { understandings of } \\
\text { scientific ideas with } \\
\text { their classmates }\end{array}$ & $\begin{array}{l}27 \\
(27 \%)\end{array}$ & $\begin{array}{l}64 \\
(64 \%)\end{array}$ & $8(8 \%)$ & $1(1 \%)$ & $0(0 \%)$ \\
\hline 5 & $\begin{array}{l}\text { Helping students } \\
\text { carry out the project, } \\
\text { it encourages them } \\
\text { to be more creative } \\
\text { and independent }\end{array}$ & $\begin{array}{l}24 \\
(24 \%)\end{array}$ & $\begin{array}{l}68 \\
(68 \%)\end{array}$ & $8(8 \%)$ & $0(0 \%)$ & $0(0 \%)$ \\
\hline 6 & $\begin{array}{l}\text { Facilitating the } \\
\text { students with a } \\
\text { group discussion } \\
\text { about designing the } \\
\text { project improves } \\
\text { their collaboration } \\
\text { and communication } \\
\text { skills }\end{array}$ & $\begin{array}{l}28 \\
(28 \%)\end{array}$ & $\begin{array}{l}66 \\
(66 \%)\end{array}$ & $6(6 \%)$ & $0(0 \%)$ & $0(0 \%)$ \\
\hline 7 & $\begin{array}{l}\text { Designing the } \\
\text { project takes up too } \\
\text { much time }\end{array}$ & $\begin{array}{l}15 \\
(15 \%)\end{array}$ & $\begin{array}{l}58 \\
(58 \%)\end{array}$ & $22(22 \%)$ & $5(5 \%)$ & $0(0 \%)$ \\
\hline
\end{tabular}


Item 3 showed that EFL Learners choose strongly agree 19\% $(n=19)$, followed by agree statement $75 \%(n=75)$, uncertain $6 \%(n=6)$, and no one considered disagree and strongly disagree. Item 4 showed that the EFL Learners choose strongly agree $27 \%$ $(n=27)$, followed by agree statement $64 \%(n=64)$, uncertain $8 \%(n=8)$, disagree $1 \%(n=1)$, and no one considered strongly disagree. Item 5 showed that the EFL Learners choose strongly agree $24 \%(n=24)$, followed by agree statement $68 \%(n=68)$, uncertain $8 \%(n=8)$, and no one considered disagree and strongly disagree. Item 6 showed that the EFL Learners choose strongly agree $28 \%(n=28)$, followed by agree statement $66 \%(n=66)$, uncertain 6\% $(n=6)$, and no one considered disagree and strongly disagree. Item 7 showed that the EFL Learners choose strongly agree $15 \%(n=15)$, followed by agree statement $58 \%(n=58)$, uncertain $22 \%(n=22)$, disagree $5 \%(n=5)$, and no one considered strongly disagree.

\begin{tabular}{|c|c|c|c|c|c|c|}
\hline Item & Statement & $\begin{array}{c}\text { Strongly } \\
\text { Agree }\end{array}$ & Agree & Uncertain & Disagree & $\begin{array}{l}\text { Strongly } \\
\text { Disagree }\end{array}$ \\
\hline \multicolumn{7}{|c|}{ Scheduling } \\
\hline 8 & $\begin{array}{l}\text { Guiding the students } \\
\text { in creating a project } \\
\text { and time preparation } \\
\text { provides learning } \\
\text { experience and } \\
\text { practice in } \\
\text { organizing projects } \\
\text { and making } \\
\text { allocation time for } \\
\text { the students }\end{array}$ & $\begin{array}{l}16 \\
(16 \%)\end{array}$ & $\begin{array}{l}77 \\
(77 \%)\end{array}$ & $6(6 \%)$ & $1(1 \%)$ & $0(0 \%)$ \\
\hline 9 & $\begin{array}{l}\text { Helping the students } \\
\text { in discussing the } \\
\text { deadline for projects } \\
\text { promotes students' } \\
\text { skill in managing } \\
\text { time }\end{array}$ & $\begin{array}{l}20 \\
(20 \%)\end{array}$ & $\begin{array}{l}67 \\
(67 \%)\end{array}$ & $12(12 \%)$ & $0(0 \%)$ & $1(1 \%)$ \\
\hline 10 & $\begin{array}{l}\text { Helping students in } \\
\text { discussing the } \\
\text { timeline for } \\
\text { completing the } \\
\text { project promotes } \\
\text { students' skill in } \\
\text { managing time }\end{array}$ & $\begin{array}{l}13 \\
(! 3 \%)\end{array}$ & $\begin{array}{l}80 \\
(80 \%)\end{array}$ & $7(7 \%)$ & $0(0 \%)$ & $0(0 \%)$ \\
\hline
\end{tabular}

Item 8 showed that the EFL learners choose strongly agree $16 \%(n=16)$, followed by agree statement $77 \%(n=77)$, uncertain $6 \%(n=6)$, disagree $1 \%(n=1)$, and no one 
considered strongly disagree. Item 9 showed that the EFL learners choose strongly agree $20 \%(n=20)$, followed by agree statement $67 \%(n=67)$, uncertain $12 \%(n=12)$, on one considered disagree, and strongly disagree $1 \%(n=1)$. Item 10 showed that the EFL Learners choose strongly agree $13 \%(n=13)$, followed by agree statement $80 \%(n=80)$, uncertain $7 \%(n=7)$, and no one considered disagree and strongly disagree.

\begin{tabular}{|c|c|c|c|c|c|c|}
\hline Item & Statement & $\begin{array}{l}\text { Strongly } \\
\text { Agree }\end{array}$ & Agree & Uncertain & Disagree & $\begin{array}{l}\text { Strongly } \\
\text { Disagree }\end{array}$ \\
\hline \multicolumn{7}{|c|}{ Monitoring } \\
\hline 11 & $\begin{array}{l}\text { Monitoring students } \\
\text { help them to be more } \\
\text { independent and } \\
\text { discipline of the } \\
\text { project }\end{array}$ & $\begin{array}{l}26 \\
(26 \%)\end{array}$ & $\begin{array}{l}67 \\
(67 \%)\end{array}$ & $7(7 \%)$ & $0(0 \%)$ & $0(0 \%)$ \\
\hline 12 & $\begin{array}{l}\text { Some students with } \\
\text { weaknesses in } \\
\text { gathering } \\
\text { information have } \\
\text { difficulties in the } \\
\text { learning process }\end{array}$ & $\begin{array}{l}17 \\
(17 \%)\end{array}$ & $\begin{array}{l}68 \\
(68 \%)\end{array}$ & $13(13 \%)$ & $2(2 \%)$ & $0(0 \%)$ \\
\hline 13 & $\begin{array}{l}\text { In the learning } \\
\text { process, some } \\
\text { students are less } \\
\text { active in group work }\end{array}$ & $\begin{array}{l}16 \\
(16 \%)\end{array}$ & $\begin{array}{l}62 \\
(62 \%)\end{array}$ & $16(16 \%)$ & $5(5 \%)$ & $1(1 \%)$ \\
\hline
\end{tabular}

The monitoring component related to item 11, 12, and 13. Item 11 showed that the EFL Learners choose strongly agree $26 \%(n=26)$, followed by agree statement $67 \%$ ( $n=67)$, uncertain $7 \%(n=7)$, and no one considered disagree and strongly disagree. Item 12 showed that the EFL Learners choose strongly agree $17 \%(n=17)$, followed by agree statement $68 \%(n=68)$, uncertain 13\% ( $n=13)$, disagree $2 \%(n=2)$, and no one considered strongly disagree. Item 13 showed that the EFL Learners choose strongly agree $16 \%$ $(n=16)$, followed by agree statement $62 \%(n=62)$, uncertain $16 \%(n=16)$, disagree $5 \%$ $(n=5)$, and strongly disagree $1 \%(n=1)$.

\begin{tabular}{|c|c|c|c|c|c|c|}
\hline Item & Statement & $\begin{array}{c}\text { Strongly } \\
\text { Agree }\end{array}$ & Agree & Uncertain & Disagree & $\begin{array}{l}\text { Strongly } \\
\text { Disagree }\end{array}$ \\
\hline \multicolumn{7}{|c|}{ Assessing } \\
\hline 14 & $\begin{array}{l}\text { Assessment helps } \\
\text { me to measure } \\
\text { students' } \\
\text { achievement and } \\
\text { supports me in }\end{array}$ & $\begin{array}{l}19 \\
(19 \%)\end{array}$ & $\begin{array}{l}78 \\
(78 \%)\end{array}$ & $3(3 \%)$ & $0(0 \%)$ & $0(0 \%)$ \\
\hline
\end{tabular}


planning the next

learning method

15

$\begin{array}{llllll}\text { Assessment provides } & 14 & 79 & 7(7 \%) & 0(0 \%) & 0(0 \%) \\ \text { feedback on the } & (14 \%) & (79 \%) & & \\ \text { amount of } & & & & \\ \text { understanding } & & & \\ \text { students have } & & & \\ \text { acquired, and shows } \\ \text { their knowledge of } \\ \text { related projects }\end{array}$

The assessing component related to item 14 and 15. Item 14 showed that the EFL Learners choose strongly agree $19 \%(n=19)$, followed by agree statement $78 \%(n=78)$, uncertain 3\% (n=3), and no one considered disagree and strongly disagree. Item 15 showed that the EFL Learners choose strongly agree 14\% ( $n=14)$, followed by agree statement $79 \%(n=79)$, uncertain $7 \%(n=7)$, and no one considered disagree and strongly disagree.

\begin{tabular}{|c|c|c|c|c|c|c|}
\hline Item & Statement & $\begin{array}{c}\text { Strongly } \\
\text { Agree }\end{array}$ & Agree & Uncertain & Disagree & $\begin{array}{l}\text { Strongly } \\
\text { Disagree }\end{array}$ \\
\hline \multicolumn{7}{|c|}{ Evaluating } \\
\hline 16 & $\begin{array}{l}\text { Guiding students to } \\
\text { conduct self- } \\
\text { assessment using a } \\
\text { study journal helps } \\
\text { them to improve } \\
\text { their performance }\end{array}$ & $\begin{array}{l}13 \\
(13 \%)\end{array}$ & $\begin{array}{l}71 \\
(71 \%)\end{array}$ & $15(15 \%)$ & $1(1 \%)$ & $0(0 \%)$ \\
\hline 17 & $\begin{array}{l}\text { Letting students } \\
\text { expressing their } \\
\text { experiences during } \\
\text { project preparation } \\
\text { and/or asking } \\
\text { questions about the } \\
\text { project keep them } \\
\text { motivated and feel } \\
\text { pleased about what } \\
\text { they have } \\
\text { accomplished }\end{array}$ & $\begin{array}{l}20 \\
(20 \%)\end{array}$ & $\begin{array}{l}75 \\
(75 \%)\end{array}$ & $5(5 \%)$ & $0(0 \%)$ & $0(0 \%)$ \\
\hline
\end{tabular}

Item 16 showed that the EFL Learners choose strongly agree 13\% $(n=13)$, followed by agree statement $71 \%(n=71)$, uncertain $15 \%(n=15)$, disagree $1 \%(n=1)$, and no one considered strongly. Item 17 showed that the EFL Learners choose strongly agree $20 \%$ 
$(n=20)$, followed by agree statement $75 \%(n=75)$, uncertain $5 \%(n=5)$, and no one considered disagree and strongly disagree.

\section{Relationship between Project-Based Learning and Collaborative Skills for EFL}

\section{Learners}

Spearman Rank Test was used to investigate a correlation between project-based learning and collaborative skills. The quantitative data were analyzed using descriptive statistics. Due to the limited number of research participants, therefore normality and heterogeneity of the sample were not statically met. Henceforth, non-parametric statistical analysis was employed to analyze the data.

\section{Table 3 Correlation Analysis}

\section{Correlations}

\begin{tabular}{|c|c|c|c|c|}
\hline & & & Rank_PJBL & $\begin{array}{c}\text { Rank_Collab } \\
\text { orative }\end{array}$ \\
\hline \multirow[t]{6}{*}{ Spearman's rho } & \multirow[t]{3}{*}{ Rank_PJBL } & Correlation Coefficient & 1.000 & $.696^{\star \star}$ \\
\hline & & Sig. (2-tailed) & . & .000 \\
\hline & & $N$ & 100 & 100 \\
\hline & \multirow[t]{3}{*}{ Rank_Collaborative } & Correlation Coefficient & $.696^{\star \pi}$ & 1.000 \\
\hline & & Sig. (2-tailed) & .000 & . \\
\hline & & $N$ & 100 & 100 \\
\hline
\end{tabular}

**. Correlation is significant at the 0.01 level (2-tailed).

The table above showed that the relationship between project based-learning (as measured by Rank-Pjbl) and collaborative skills (as measured by the Rank-Collaborative) was investigated using Spearman Rank Test. It was clear that the value of significant generated Sig. (P-value) $=0.000<\alpha=0.05$. It meant Ha was accepted. Based on the computation, it could be concluded that there was a correlation between project-based learning and EFL Learners' collaborative skills at University in Indonesia. The strongest correlation coefficient for Project-based learning was with collaborative skill: rho (100) $=0.696, \mathrm{p}<.001$.

\section{Discussion}

The first finding of this research set out to measure EFL learners' perception of project-based learning. The statistical results indicate that the learners' perception of PBL is positive. This evidence adds to the consistent findings of past research on PBL perceptions. Using or implementing PBL could promote learners' motivation and active 
learning (Rasyid \& Khoirunnisa, 2021). It also encourages collaboration (Kurniawati, Susanto, \& Munir, 2019), communication (Musa, Mufti, Latiff, \& Amin, 2012), and independent learning. PBL also improves EFL learners' knowledge (Almulla, 2020), problem-solving skills (Wahyuni, 2014), time management skills, and creativity (Yamin, Permanasari, Redjeki, \& Sopandi, 2020) (Wijayati, Sumarni, \& Supanti, 2020), and leadership skill (Musa et al., 2011). In addition, using PBL can give a new atmosphere to increase critical thinking, communication, collaboration, and creativity or 4Cs skills (Karyawati \& Ashadi, 2018).

The second finding of this research is to examine the relationship between projectbased learning and learners' collaborative skill. The statistical findings indicate a strong relationship between project-based learning and learners' collaborative skill. Some previous studies support this evidence. Using project-based learning positively impacts collaborative skills in higher education (Lou \& Kim MacGregor, 2004) (Kurniawati et al., 2019). This finding also showed some indicators of collaborative skills such as teamwork, cooperative learning, and brainstorming related to project-based learning for EFL learners. Some findings reported the positive correlation between teamwork or group work and motivation between project-based learning (Filippatou \& Kaldi, 2010) and cooperative learning (Boondee, Kidrakarn, \& Sa-Ngiamvibool, 2011).

\section{CONCLUSION}

The purposes of the current study were: (1) to measure EFL learners' perceived project-based learning, (2) to examine whether project-based learning was related to leaners' collaborative skills. The finding showed that more than $70 \%$ of learners perceived project-based learning for EFL classrooms. The results indicated that using PBL positively impacts EFL learners, improving learners' motivation, communication, collaboration, and problem-solving skills. The subsequent finding is related to the second research question. Based on the statistical result of correlation research, it concluded that there is a strong correlation between PBL and collaborative skill for EFL learners at University. 


\section{REFERENCES}

Almulla, M. A. (2020). The effectiveness of the project-based learning (PBL) approach as a way to engage students in learning. SAGE Open, 10(3). https://doi.org/10.1177/2158244020938702

Alyani, A. A. (2021). Students' perception of project - based learning in microteaching class. Journal of English Language Teaching 10(3), 436-448. https://doi.org/10.24036/jelt.v10i3.113874

Boondee, V., Kidrakarn, P., \& Sa-Ngiamvibool, W. (2011). A learning and teaching model using project-based learning (PBL) on the web to promote cooperative learning. European Journal of Social Sciences, 21(3), 498-506.

Daly, S. R., Mosyjowski, E. A., Oprea, S. L., Huang-Saad, A., \& Seifert, C. M. (2016). College students' views of creative process instruction across disciplines. Thinking Skills and Creativity, 22, 1-13. https://doi.org/10.1016/j.tsc.2016.07.002

Filippatou, D., \& Kaldi, S. (2010). Within the context of student-centered learning, project-based teaching method has become increasingly prominent as a response of schooling to the challenges of the 21. International Journal of Special Education, 25(1), 17-26.

Heong, Y. M., Yunos, J. M., Othman, W., Hassan, R., Kiong, T. T., \& Mohamad, M. M. (2012). The needs analysis of learning higher order thinking skills for generating ideas. Procedia - Social and Behavioral Sciences, 59, 197-203. https://doi.org/10.1016/j.sbspro.2012.09.265

Jahnke, I., Haertel, T., \& Wildt, J. (2017). Teachers' conceptions of student creativity in higher education. Innovations in Education and Teaching International, 54(1), 8795. https://doi.org/10.1080/14703297.2015.1088396

Karyawati, A., \& Ashadi, A. (2018). Innovation in the classroom: Engaging English as a foreign learning students using project-based learning. LingTera, 5(1), 61-67. https://doi.org/10.21831/lt.v5i1.17067

Kurniawati, F. N., Susanto, S., \& Munir, A. (2019). Promoting students' collaboration skill through project based learning of English writing. ANGLO-SAXON: Jurnal Ilmiah Program Studi Pendidikan Bahasa Inggris, 10(1), 29. https://doi.org/10.33373/anglo.v10i1.1890

Laal, M., \& Ghodsi, S. M. (2012). Benefits of collaborative learning. Procedia - Social and Behavioral Sciences, 31(2011), 486-490. https://doi.org/10.1016/j.sbspro.2011.12.091

Lam, N. T. Van. (2011). Project-based learning in teaching English as a foreign language. VNU Journal of Science, 27, 140-146. Retrieved from http://repository.vnu.edu.vn/bitstream/VNU_123/58517/1/27.2.8.pdf

Lou, Y., \& Kim MacGregor, S. (2004). Enhancing project-based learning through online between-group collaboration. Educational Research and Evaluation, 10(4-6), 419440. https://doi.org/10.1080/13803610512331383509

Musa, F., Mufti, N., Latiff, R. A., \& Amin, M. M. (2011). Project-based learning: Promoting meaningful language learning for workplace skills. Procedia - Social and Behavioral Sciences, 18, 187-195. https://doi.org/10.1016/j.sbspro.2011.05.027

Musa, F., Mufti, N., Latiff, R. A., \& Amin, M. M. (2012). Project-based learning (PBL): inculcating soft skills in 21st century workplace. Procedia - Social and Behavioral Sciences, 59(2006), 565-573. https://doi.org/10.1016/j.sbspro.2012.09.315

Ngadiso, N., Sarosa, T., Asrori, M., Drajati, N. A., \& Handayani, A. (2021). Project-based learning (PBL) in EFL learning: Lesson from Indonesia. AL-ISHLAH: Jurnal 
Pendidikan, 13(2), 1114-1122. https://doi.org/10.35445/alishlah.v13i2.558

Rao, P. S. (2019). Collaborative learning in English language classrooms. ACADEMICIA: An International Multidisciplinary Research Journal, 9(2), 5. https://doi.org/10.5958/2249-7137.2019.00020.x

Rasyid, M. Al, \& Khoirunnisa, F. (2021). The Effect of project-based learning on collaboration skills of high school students. Jurnal Pendidikan Sains (Jps), 9(1), 113. https://doi.org/10.26714/jps.9.1.2021.113-119

Reddy, M. V. B., \& Panacharoensawad, B. (2017). Students problem-solving difficulties and implications in physics: An empirical study on influencing factors. Journal of Education and Practice, 8(14), 59-62.

RI, D. J. P. T. kemendikbud. (2020). Buku panduan IKU perguruan tinggi negeri (I). Jakarta: Direktorat Jenderal Pendidikan Tinggi Kemendikbud R!

Tsiplakides, I., \& Fragoulis, I. (2009). Project-based learning in the teaching of English as a foreign language in Greek primary schools: From theory to practice. English Language Teaching, 2(3), 113-119. https://doi.org/10.5539/elt.v2n3p113

Wahyuni, S. (2014). the Implementation of project-based learning to direct students in writing a research proposal. Language Circle - Journal of Language and Literature, 8(2), 193-205. https://doi.org/10.15294/lc.v8i2.3023

Wijayati, N., Sumarni, W., \& Supanti, S. (2020). Improving student creative thinking skills through project based learning. (July 2019). https://doi.org/10.18502/kss.v3i18.4732

Wongdaeng, M., \& Hajihama, S. (2018). Perceptions of project-based learning on promoting 21 st century skills and learning motivation in a Thai EFL setting. JSEL, 13(2), 158-190.

Yamin, Y., Permanasari, A., Redjeki, S., \& Sopandi, W. (2020). Project based learning to enhance creative thinking skills of the non-science students. Jhss (Journal of Humanities and Social Studies), 4(2), 107-111. https://doi.org/10.33751/jhss.v4i2.2450 